\title{
Metabolite pattern of Cysticercus cellulosae metacestode FROM DIFFERENT PREDILECTION SITES OF SWINE USING PROTON MAGNETIC RESONANCE SPECTROSCOPY
}

\author{
CHAWLA S.", KUMAR S.", GARG M.*, KUMAR R.*, ROY R.** \& GUPTA R.K.*
}

\section{Summary:}

Cysticercosis due to Taenia solium is one of the most common public health problems in various regions of the world. We have performed proton magnetic resonance spectroscopy ('H MRS) experiments of the fluid aspirated from cysticerci excised from skeletal muscle $(n=16)$ and brain $(n=9)$ of infected swine to compare the metabolite pattern of cysticerci in different predilection sites. Perchloric acid extract of cysticercus cysts excised from skeletal muscles $(n=16)$ was also prepared to ascertain water-soluble, low molecular weight metabolites using 'H MRS. Absolute quantification and statistical analysis of different metabolites was done to look for any significant differences in different locations of cysts. The metabolite pattern of cysticerci was found to be similar in the various predilection sites. Metabolites observed were leucine, valine, alanine, lysine, glycine, lipid contents, lactate, glutamate, acetate, succinate, creatine, choline, and glucose. Concentration of creatine in cysticercus fluid of cysts removed from the muscle was found to be significantly higher $(p=$ 0.0011 than the cysts located in the brain. We conclude that the metabolite pattern in the cysticerci is not influenced by the surrounding tissue location; however concentration of certain metabolites may depend upon the tissue location.

KEY WORDS : porcine cysticercosis, Cysticercus cellulosae, proton magnetic resonance spectroscopy, swine, metabolites.
Résumé : COMPARAISON DES PROFILS MÉTABOLIOUES DES MÉTACESTODFS DE CYSTICERCLS CELLULOSAE PROVENANT DE DIFFÉRENTS SITES DE PRÉDILECTION CHEZ LE PORC PAR LA TECHNIQUE DE SPECTROSCOPIE DE RÉSONANCE MAGNÉTIQUE DE PROTON

Le téniasis du à Taenia solium est l'un des problèmes de santé publique les plus communs dans beaucoup de régions du monde. Nous avons utilisé la technique de spectrométrie de résonance magnétique ('H MRS) sur des fluides aspirés de cysticerques excisés de muscle du squelette $(n=16)$ et du cerveau $(n=9)$ de porcs infectés pour comparer les profils métaboliques de cysticerques provenant de différents sites de prédilection du parasite. Des extraits perchloriques de kystes excisés de muscles du squelette $(n=16)$ ont été aussi préparés pour déterminer les métabolites de bas poids moléculaire solubles dans l'eau par la même technique. La quantification et l'analyse statistique des différents métabolites ont été étudiées de façon à repérer des différences significatives selon les sites de provenance des kystes. Le profil métabolique des cysticerques reste semblable quel que soit le site étudié. Les métabolites retrouvés sont la leucine, la valine, l'alanine, la lysine, la glycine, le contenu lipidique, les acides lactiques, glutamiques, acétique, succinique, la créatine, la choline et le glucose. La concentration de créatine du fluide des cysticerques de muscles était significativement supérieure $l p=$ 0,0011 à celle des fluides de cysticerques du cerveau. En conclusion, nous pouvons dire que le profil métabolique des cysticerques ne dépend généralement pas des tissus d'origine, mais que la concentration de métabolites particuliers peut en dépendre.

MOTS CLÉS : cysticercose, Cysticercus cellulosae, spectroscopie de résonance magnétique de proton, porc, métabolites.

\section{INTRODUCTION}

$\mathrm{P}$ arasitic helminths are heterogeneous organisms, responsible for a variety of diseases in different regions of the world. Cysticercus cellulosae, the metacestode of the pork tapeworm (Taenia solium) causes cysticercosis, one of the most common public

\footnotetext{
* Department of Radiodiagnosis, Sanjay Gandhi Post-graduate Institute of Medical Sciences, Regional Sophisticated Instrumentation Centre, Lucknow, UP, India.

** Central Drug Research Institute, Lucknow, UP, India. Correspondence: Dr. Rakesh K. Gupta, MD. MR Section, Department of Radiodiagnosis, SGPGIMS, Lucknow-226014, India.

Tel.: +91 522 2668700, ext. 2599 - Fax: +91-522-2668017, 2668973.

E-mail: rgupta@sgpgi.ac.in - rakeshree@hotmail.com
}

health problems worldwide including India. T. solium completes its life cycle in two natural hosts, swine as normal intermediate host, harbouring the cysticercus and humans as the definitive host, harboring the adult form (Nash et al., 1984). Cysticercosis is endemic in Mexico, Latin America, Sub-Saharan Africa, Asia, and Europe (Rodriguez-Carbajal et al., 1987). In India, the prevalence of cysticercosis in swine has been reported to be $18 \%$ (Pathak et al., 1983) and high proportion of pork is rejected due to this infection (Pathak \& Gaur, $1988,1989)$. In rural areas, where meat inspection is usually not performed, the number of animals affected by the disease may be much higher. This is due to the fact that swine walk about freely, feeding intentionally or unintentionally on human faecal matter, which may contain ova or gravid proglottids of $T$. solium. In swine, 
cystic larvae usually lodge in skeletal muscle, brain, heart, lungs and liver (Flisser et al., 1990; Grewal et al., 2000).

The wide range of metabolites that can be detected with a single experiment makes proton magnetic resonance spectroscopy ( ${ }^{1} \mathrm{H}$ MRS) a powerful tool for uncovering novel biochemical markers (Gupta et al., 1996). ${ }^{1} \mathrm{H}$ MRS has been found to be very useful in differentiation of intracranial cystic lesions with similar magnetic resonance imaging (MRI) features (ShuklaDave et al., 2001). Although there are anecdotal ${ }^{1} \mathrm{H}$ MRS studies (Chang et al., 1998; Pandit et al., 2001) documenting the metabolites in neurocysticercosis in humans, however, to the best of our knowledge, there is no study describing the metabolite pattern of cysticercosis in different tissue locations in the natural hosts of T. solium. We have performed ${ }^{1} \mathrm{H}$ MRS experiments of the cysticercus fluid to compare the metabolites of this larval stage in different predilection sites of swine. The extrapolation of this information may be of value in humans for in vivo characterization of this parasitic cyst in different locations non-invasively.

\section{MATERIALS AND METHODS}

S keletal muscles and brains of freshly slaughtered swine naturally infected with cysticerci were procured from a local abattoir and were wrapped around in ice cubes of saline immediately. Cysts were excised from these organs and were stored in normal saline at $4^{\circ} \mathrm{C}$ (Fan et al., 1998).

Cystic fluid $(100 \mu \mathrm{l})$ aspirated with the help of a micro syringe from cysticerci excised from skeletal muscle $(\mathrm{n}=16)$ and brain $(\mathrm{n}=9)$ was transferred to a $5 \mathrm{~mm}$ NMR tube. Adequate care was taken to avoid any contamination from the surrounding tissue. Deuterium oxide (Sigma Aldrich, USA) was added as an internal magnetic field lock. This was subjected to ${ }^{1} \mathrm{H}$ MRS experiments to ascertain the various metabolites.

Perchloric acid (PCA extract): PCA extract of cysticerci excised from skeletal muscles of swine $(n=16)$ was prepared using a standard technique (Glonek et al., 1982). PCA causes acid hydrolysis of fatty acids and extracts only low molecular weight water-soluble metabolites. This helps in better resolved spectra and more precise interpretation of different metabolites, as these are not concealed by broad resonances of lipids.

The ${ }^{1} \mathrm{H}$ MRS experiments were performed at $25^{\circ} \mathrm{C}$ on a 7.1 T (Bruker Avance 300 DRX, Faellanden, Switzerland) NMR spectrometer operating at $300.13 \mathrm{MHz}$ frequency equipped with a $5 \mathrm{~mm}$ multinuclear inverse probe head with Z-shielded gradient. Standard onedimensional (1D) experiments were performed using two different sequences; a single pulse sequence to document various metabolites, which will have the same phase and a spin-echo (SE) sequence $(\mathrm{TE}=$ $160 \mathrm{~ms}$ ) for spectral editing of longer $\mathrm{T}_{2}$ components as well as to see the phase reversal of the J-coupled multiplets. Typical parameters for obtaining 1D spectrum were: $32 \mathrm{~K}$ data points, spectral width $3,500 \mathrm{~Hz}$, 128 scans, flip angle $90^{\circ}$, relaxation delay $5 \mathrm{~s}$ (Kniju et al., 2000). Data were Fourier transformed with $0.3 \mathrm{~Hz}$ line broadening. Standard two-dimensional (2D) correlation spectra $\left(\operatorname{COSY}-90^{\circ}\right)$ were also acquired with frequency selective water presaturation. The spectral width was $3,591 \mathrm{~Hz}$ in both the directions, $256 \mathrm{t}_{1}$ increments in the $2 \mathrm{~s}$ recycle delay. For each $\mathrm{t}_{1}$ step, 16 transients were added with $1 \mathrm{~K}$ data points. The data were weighted with sine bell window function in both dimensions before double Fourier transformation. The final matrix had $1,024 \times 256$ data points. Chemical shifts in parts per million (ppm) of all resonances were measured with respect to the chemical shift position of sodium salt of 3-(trimethylsilyl) - 2, 2, 3, 3- $\mathrm{d}_{4}$-propionate (TSP) centered at $0.0 \mathrm{ppm}$. Assignment of various peaks was done on the basis of existing literature (Sweatman et al., 1993; Govindaraju et al., 2000).

\section{ABSOLUTE QUANTIFICATION OF METABOLITES}

For absolute quantification, a capillary tube containing $0.75 \%(\mathrm{w} / \mathrm{v})$ of TSP (Sigma Aldrich, USA) in $\mathrm{D}_{2} \mathrm{O}$ was inserted in all the sample tubes. Phase and baseline correction was done before measuring the integral values of TSP and all other metabolites. The standard software program NMRQUANT available on the spectrometer was then used to calculate the absolute concentration of all the metabolites with respect to the known concentration of TSP in the capillary.

\section{STATISTICAL ANALYSIS OF METABOLITES}

For statistical analysis, a two-tailed heteroscedastic student's t-test, which is part of the Windows-based MS Excel program, was used. Probability $(p)$ values were computed for different metabolite concentrations of the cysticercus fluid from muscle and brain to look for any significant differences. The p-values of less than 0.05 were regarded as statistically significant.

\section{RESULTS}

The results are presented in Table I. The ${ }^{1} \mathrm{H}$ MRS indicate that there was no difference in the spectral patterns obtained from skeletal muscle and cerebral cysts.

The complex multiplet centered at $0.9 \mathrm{ppm}$ was detected in single pulse spectra from cysticercus cyst from skeletal muscle (Fig. 1a). This multiplet was assi- 


\begin{tabular}{|c|c|c|c|}
\hline \multirow[b]{2}{*}{ Metabolites } & \multirow[b]{2}{*}{$\begin{array}{l}\text { Quantitation } \\
\text { on* }\end{array}$} & \multicolumn{2}{|c|}{$\begin{array}{c}\text { Concentration of } \\
\text { of cysticercus fluid } \\
\text { in } \mathrm{mM} \text { as Mean } \pm \mathrm{SD}\end{array}$} \\
\hline & & $\begin{array}{l}\text { Muscle } \\
(\mathrm{n}=16)\end{array}$ & $\begin{array}{l}\text { Brain } \\
(\mathrm{n}=9)\end{array}$ \\
\hline Lactate & $1.33 \mathrm{~d}\left[\mathrm{CH}_{3}\right]$ & $27.02 \pm 30.32$ & $6.30 \pm 4.29$ \\
\hline Alanine & $1.47 \mathrm{~d}\left[\mathrm{CH}_{3}\right]$ & $4.83 \pm 4.54$ & $4.77 \pm 3.30$ \\
\hline Acetate & $1.92 \mathrm{~s}\left[\mathrm{CH}_{3}\right]$ & $1.53 \pm 1.08$ & $1.25 \pm 0.93$ \\
\hline Succinate & $2.40 \mathrm{~s}\left[\mathrm{CH}_{2}\right]$ & $1.98 \pm 1.78$ & $1.17 \pm 0.88$ \\
\hline Creatine $e^{* * *}$ & $3.03 \mathrm{~s}\left[\mathrm{~N}\left(\mathrm{CH}_{3}\right)\right]$ & $2.52 \pm 0.91$ & $0.817 \pm 0.50$ \\
\hline Glycine & $3.56 \mathrm{~s}\left[\mathrm{CH}_{2}\right]$ & $6.26 \pm 5.33$ & $2.09 \pm 1.25$ \\
\hline$\beta$-Glucose & $4.64 \mathrm{~d}\left[\mathrm{CH}_{1}\right]$ & $9.27 \pm 9.19$ & $4.023 \pm 3.18$ \\
\hline$\alpha$-Glucose & $5.23 \mathrm{~d}\left[\mathrm{CH}_{1}\right]$ & $12.50 \pm 7.84$ & $9.714 \pm 6.85$ \\
\hline
\end{tabular}

"Where, $\mathrm{d}$ = doublet; $\mathrm{s}=$ singlet. Groups given in the parentheses specify the chemical shift position where integration was done and number of protons used for measuring the concentration of respective metabolites.

*** Creatine was present in significantly higher concentration $(\mathrm{p}=$ 0.001 ) in the muscle compared to brain. In rest of the metabolites, the difference in the concentration from these two locations was not found to be statistically significant $(p>0.05)$.

Table I. - Quantitative analysis of various metabolites.
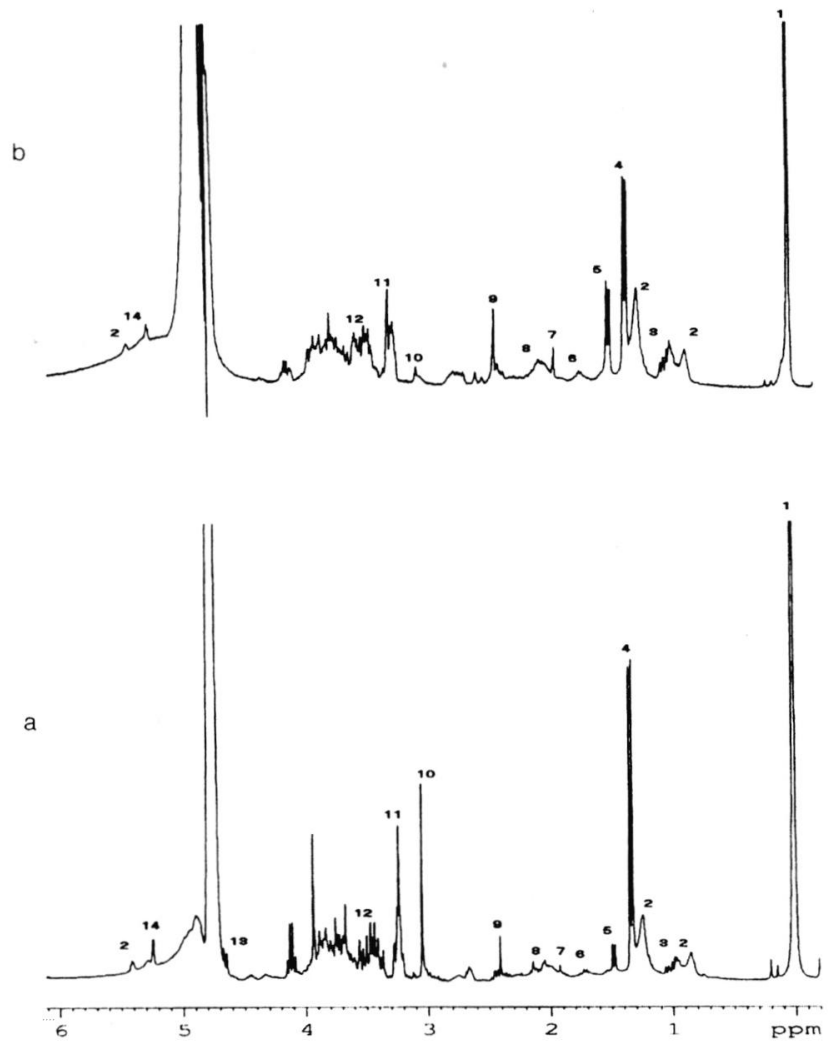

Fig. 1. - Single pulse ${ }^{1} \mathrm{H}$ MRS of Cysticercus cyst fluid from (a) skeletal muscle and (b) brain of swine showing TSP (1), Lipid (2), Amino acids [Valine (Val), Isoleucine (Ile), and Leucine (Leu); 3], Lactate (4), Alanine (5), Lysine (6), Acetate (7), Glutamate/Glutamine (8), Succinate (9), Creatine (10), Choline containing compounds (11), Glycine (12), b-Glucose (13), a-Glucose (14). Note the large Creatine peak at $3.03 \mathrm{ppm}$ in (a) compared to (b).
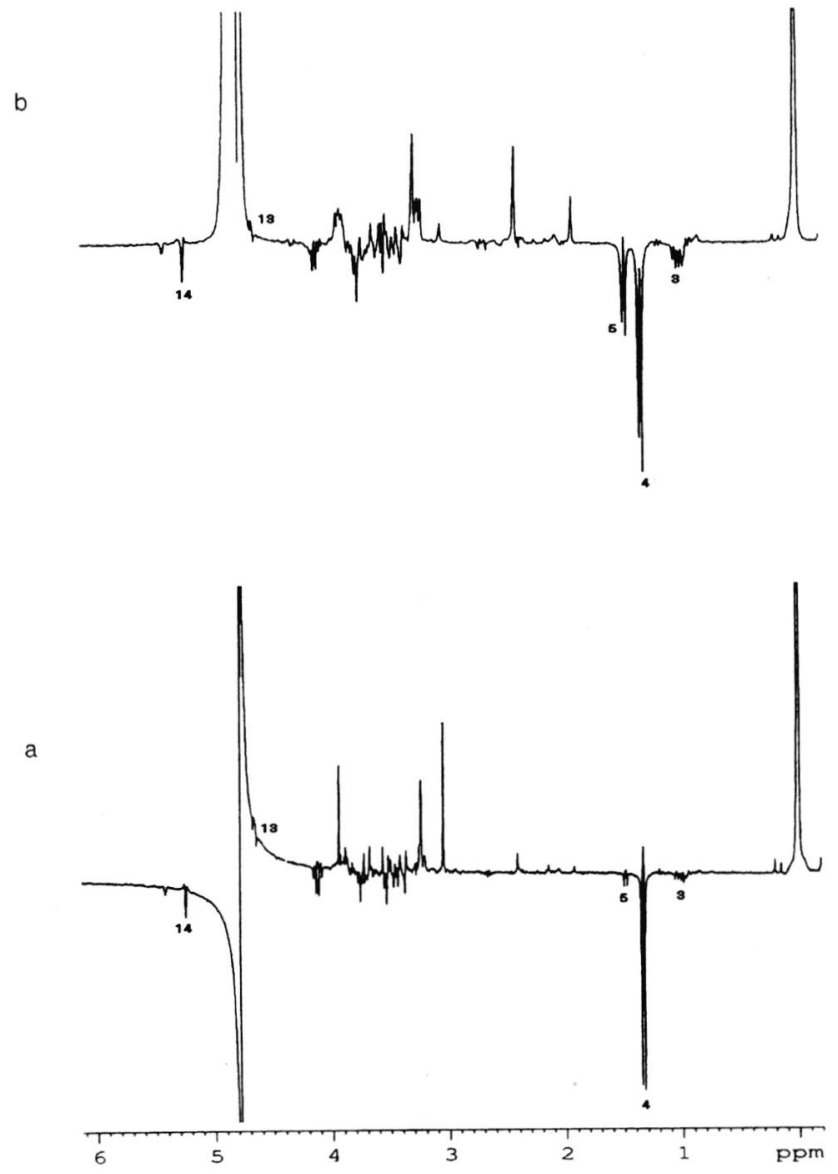

Fig. 2. - Spin echo $(\mathrm{TE}=160 \mathrm{~ms}){ }^{1} \mathrm{H}$ MRS of Cysticercus fluid from (a) skeletal muscle and (b) brain of swine show the phase reversal of Amino acids (3), Lactate (4), Alanine (5), $\beta$-Glucose (13) and $\alpha$ Glucose (14).

gned to cytosolic amino acids on the basis of its inversion in SE experiment (Fig. 2a). 2D COSY data indicate that these amino acids were mainly leucine, isoleucine and valine (Fig. 3a). A broad resonance at $0.9 \mathrm{ppm}$, not appearing in SE, was interpreted as terminal methyl group $\left(-\mathrm{CH}_{3}\right)$ of the long chain fatty acids from mobile lipids. At $1.3 \mathrm{ppm}$, a sharp doublet along with upfield broad shouldering was seen in the single pulse experiment. This doublet was found to have reversed phase in SE because of J-coupling with reduced signal intensity, suggesting presence of lactate and fatty acyl chain $\left(-\mathrm{CH}_{2}\right) \mathrm{n}$. Presence of lactate was confirmed by $2 \mathrm{D}$ experiment where a doublet at $1.33 \mathrm{ppm}$ due to $-\mathrm{CH}_{3}$ was found to correlate with a quadruplet at $4.11 \mathrm{ppm}$ due to a-CH $1 \mathrm{H} \mathrm{s}$. Similarly, alanine showed signals at $1.47 \mathrm{ppm}$ (doublet) and 3.76 ppm (quadruplet). Two other amino acids lysine (1.45, $1.73,3.01 \mathrm{ppm})$ and glutamate/glutamine (2.09, 2.34 ppm) were also seen. Resonances due to fatty acyl chain from lipids were also observed and assigned to 

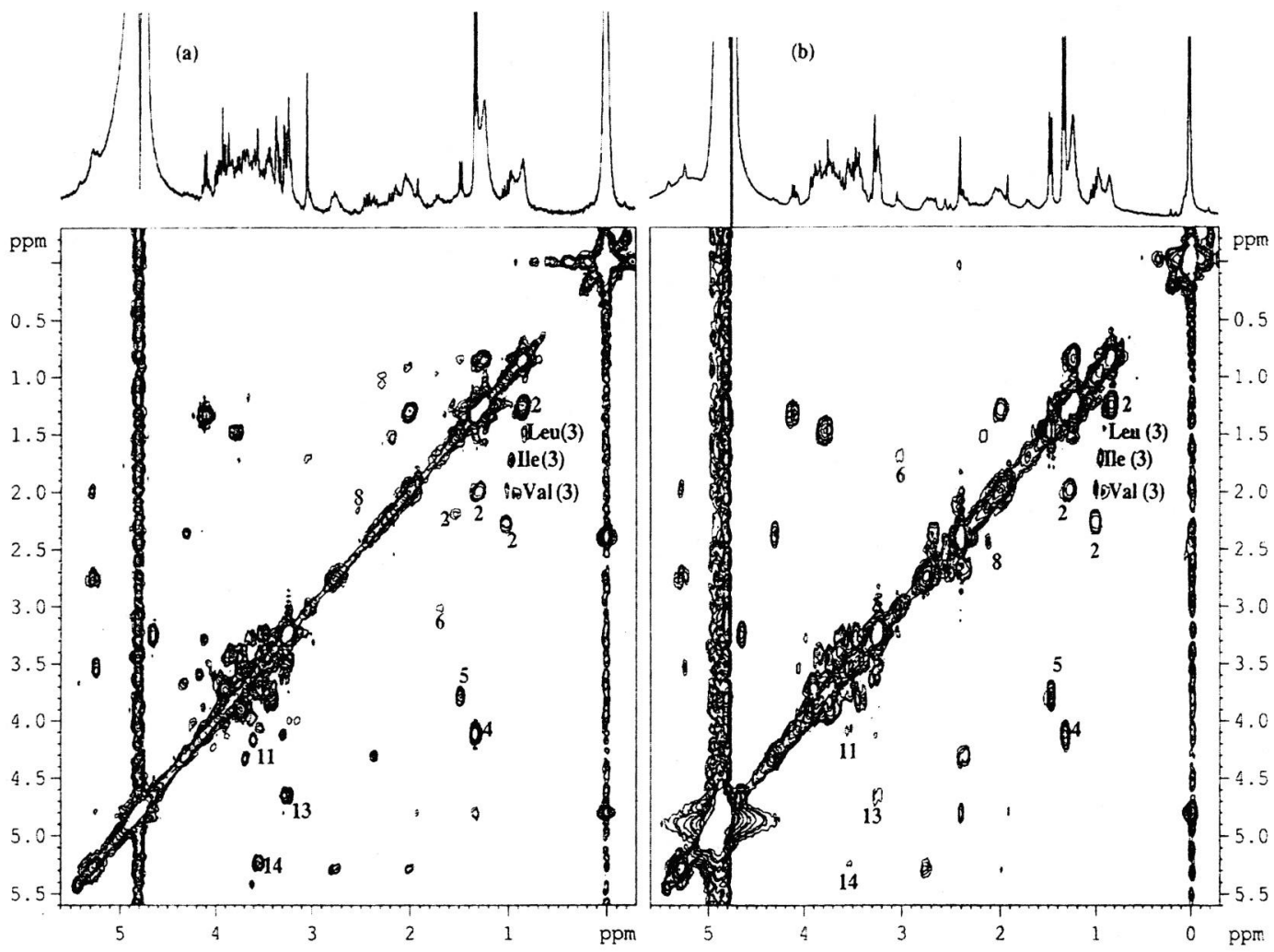

Fig. 3. - 2D COSY spectra of Cysticercus fluid from (a) skeletal muscle and (b) brain of swine confirming the resonances seen on single pulse ${ }^{1} \mathrm{H}$ MRS. The numbers represent the assignments as in Figure 1.

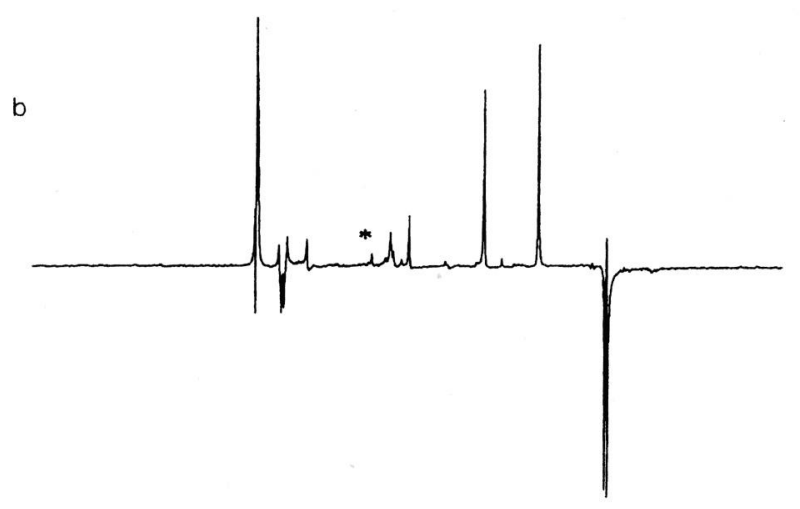

olefinic groups of lipids such as $-\mathrm{CH}_{2}=\mathrm{CH}-(2.02$ ppm); $=\mathrm{CH}-\mathrm{CH}_{2}-\mathrm{CH}=(2.80 \mathrm{ppm}) ;-\mathrm{CH}=\mathrm{CH}-$ $(5.34 \mathrm{ppm})$. Resonances seen in single pulse spectrum assigned to lipids were not visible in SE spectrum due to their shorter $\mathrm{T}_{2}$ relaxations, substantiating that these resonances were due to different lipid components only. A detailed study for assignment of these different lipid components has not been carried out, thus it is not certain whether these signals correspond to mobile lipids (Kuesel et al., 1994) or different lipoproteins (Chylomicrons, low density lipoproteins, and high density lipoproteins) (Bell et al., 1992) or both. Three singlets centered at 1.92, 2.4, and $3.56 \mathrm{ppm}$ were due to acetate, succinate, and glycine respectively. Resonance at $3.22 \mathrm{ppm}$ was identified as choline containing compounds (free choline, phosphocholine and glycerophosphocholine). Two resonances seen at 3.02 and $3.93 \mathrm{ppm}$ were assigned to creatine. These resonances showed relative integration value in the ratio of $3: 2$ on $1 \mathrm{D}$ confirming the N-methyl (3.03 ppm) and $\mathrm{N}$-methylene $(3.93 \mathrm{ppm})$ groups of creatine. Two doublets seen at $5.23 \mathrm{ppm}$ and $4.64 \mathrm{ppm}$ were assigned

a

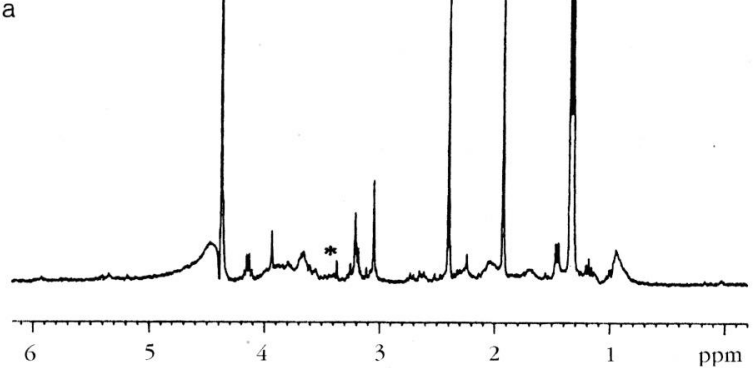

Fig. 4. - Single pulse (a) spin echo $(\mathrm{TE}=160 \mathrm{~ms})(\mathrm{b}){ }^{1} \mathrm{H}$ MRS of PCA extract of cysticerci from skeletal muscle of swine showing only water soluble metabolites. Note the presence of unassigned metabolite $\left(^{*}\right)$ at $3.36 \mathrm{ppm}$ and absence of broad lipid resonances seen in Figures 1-3. 
to anomeric (C1-H) $1 \mathrm{H} \mathrm{s}$ of $\alpha$ - and $\beta$-glucose respectively (Hausen et al., 2002) that showed correlations with other resonances in 2D spectra. Similar metabolite pattern was also obtained in fluid aspirated from cysticercus cysts located in the brain (Figs 1b-3b).

All the low molecular weight water-soluble metabolites seen on ${ }^{1} \mathrm{H}$ MRS of fluid aspirated from cysticerci were also visible in PCA extract. In addition, a singlet at $3.36 \mathrm{ppm}$ was also seen that could not be assigned (Fig. 4).

\section{ABSOLUTE QUANTIFICATION AND STATISTICAL ANALYSIS OF METABOLITES}

Concentration of various metabolites as $\mathrm{mM}$ [mean \pm standard deviation (SD)] is summarized in Table I. It was not possible to quantify leucine and valine because of overlap of resonances and also due to the presence of broad lipid peaks at the same position. Peaks of glutamate and lysine were too small to be quantified. Choline and other choline-containing compounds could not also be quantified due to the spectral crowding as the signals merged with those of other metabolites in the same spectral region. Among the metabolites that were quantified in this study, concentration of creatine was found to be significantly higher $(p=0.001)$ in the cystic fluid of the parasite present in the muscle compared to that of the brain. In rest of the metabolites, the difference in the concentration from these two locations was not found to be statistically significant $(p>0.05)$.

\section{DISCUSSION}

T $\mathrm{n}$ the present study, by and large no noteworthy differences were observed in metabolite pattern of cysticerci from the brain and skeletal muscle of the infected swine. This comparable metabolite pattern in cysts from swine implies that the parasite follows similar biochemical pathways even when present in different tissue locations.

It is documented that helminths utilize either aerobic or anaerobic pathways in accordance with oxygen availability in the environment (Kohler, 1985). However the current observation suggests that anaerobic metabolic pathway is dominant in these cysts. The pathway for biosynthesis of lactate and acetate is anaerobic fermentation of pyruvate. Phosphoenolpyruvate formed during glycolysis partially transforms to oxaloacetate and undergoes a cascade of reactions to form succinate (McManus et al., 1995). Succinate has also been known to exist in the scolices of cysticerci (del Arenal Mena et al., 1998).

Transamination of pyruvate produces leucine, valine and alanine. The occurrence of free amino acids is regarded as an intracellular pool deposition consisting of com- ponents derived from surrounding host tissues and catabolic components, resulting from protein degradation and other metabolic transformations occurring within the parasite. Presence of alanine has been regarded as an end product of pyruvate metabolism in several helminths with glutamate acting as an amino donor (Hurd, 1989). Chen et al. have quantified 18 free amino acids in cystic fluid of subcutaneous and cerebral cysticercus cysts of swine origin by means of auto amino acid analyzer. They observed alanine as the predominant amino acid in the cysts from both the organs along with glycine, proline and threonine (Chen et al., 1990). We have also observed a prominent doublet at $1.47 \mathrm{ppm}$ and a singlet at $3.56 \mathrm{ppm}$ on ${ }^{1} \mathrm{H}$ MRS experiments consistent with alanine and glycine respectively. We have also found very small resonances of glutamate and lysine. However, we did not find proline and threonine in the present study.

Tegument lining the bladder wall of cysticercus cyst is known to have a loose arrangement of muscle fibers between the nuclei and appears as thin bundles in well-distended bladder wall and slightly thick bundles in collapsed bladder wall and this finding has been confirmed on histopathological studies (Gutierrez, 2000). It appears that the presence of creatine in the fluid of the cysticercus cyst is due to the metabolically active muscle fibers in the bladder wall of the cyst. However, concentration of creatine in muscular cystic fluid was found to be significantly higher $(p=0.001)$ than cerebral cystic fluid. In view of relatively larger concentration of creatine in the skeletal muscle as compared to brain (Kirchberger et al., 1984), it is likely that creatine from the surrounding skeletal muscles may diffuses through the cyst wall to produce higher creatine concentration.

Choline peak at $3.22 \mathrm{ppm}$ encompasses signals primarily from phosphocholine and glycerophosphocholine. Phosphocholine is a precursor and glycerophosphocholine is a by-product of membrane phosphatidyl choline metabolism. Detection of choline containing compounds on ${ }^{1} \mathrm{H}$ MRS is considered as a marker for cell density and cell membrane proliferation (Venkatesh et al., 2001). The presence of choline containing compounds in the cystic cavity has been shown in some of the cystic gliomas (Poptani et al., 1995). Presence of a large choline resonance is an unusual finding from the fluid of these cysts. It is likely that it is released from the membrane and is pooled in the cyst fluid. Lipid is an important constituent of cell membrane of the parasite. It appears that the metabolite alteration in the cell membranes is probably contributing to presence of various lipids observed on spectroscopy in the cyst fluid of the parasite.

${ }^{1} \mathrm{H}$ MRS has played an important role in the characterization of various intracranial cystic lesions as it provides metabolite information that may be used as mar- 
kers for non-invasive diagnosis (Kohli et al., 1995; Gupta et al., 2001). Recently, an attempt has been made to predict the viability of hydatid cysts using ${ }^{1} \mathrm{H}$ MRS. Metabolites observed in this study were leucine/valine, lactate, alanine, acetate, succinate, choline, glycine, and glucose. When hydatid cysts were fertile, in addition to the above metabolites, resonances from malate and/or fumarate were also noticed (Garg et al., 2002a). Chang et al have described in vivo ${ }^{1} \mathrm{H}$ MRS findings in human cysticercus cysts. The metabolites observed in their study were lactate, acetate, alanine, succinate and an unassigned resonance at $3.3 \mathrm{ppm}$ (Chang et al., 1998). In another study of cystic intra axial lesion in brain, Pandit et al have observed elevated lactate, alanine, succinate, choline levels and reduced levels of N-acetyl aspartate (NAA) and creatine (Pandit et al., 2001). Metabolite pattern has shown to be similar in cysticercus fluid from the humans and swine (Garg et al., 2002b). We observed most of the metabolites seen in these two studies. In addition, we also observed leucine, valine, glycine, glutamate, lysine, lipid components and glucose molecules. The ${ }^{1} \mathrm{H}$ MRS experiments in the present study do not show the presence of NAA as suggested by Pandit et al. This confirms that NAA observed on in vivo spectroscopy of the cysticercus cyst of the brain is a contamination of the voxel by the adjoining brain parenchyma. This observation suggests that ex vivo studies serve as a benchmark for assignment of the metabolites that are likely to be observed in a focal lesion in vivo.

We conclude that metabolite pattern in the cysticerci are essentially not influenced by the surrounding tissue. This information may be of value in characterization of similar MRI appearing cystic lesions in different tissue locations in humans on in vivo ${ }^{1} \mathrm{H}$ MRS

\section{ACKNOWLEDGEMENTS}

Siving anjeev Chawla acknowledges the financial assistance from Council of Scientific and Industrial Research, New Delhi, India. The work was supported by the grant from Department of Science and Technology, India (DST NO. SP/SO/B-45/97).

\section{REFERENCES}

Bell J.D. \& SADLER P. Body fluids, in: Encyclopedia of nuclear magnetic resonance. Grant D.M. \& Harris R.K. (eds), John Wiley \& Sons Ltd, England, 1992, 989-1001.

Chang K.H., Song I.C., Kim S.H., Han M.H., Kim H.D., SeOng S.O., Jung H.W. \& Han M.C. In vivo single-voxel ${ }^{1} \mathrm{H}$ MR spectroscopy in intracranial cystic masses. American Journal of Neuroradiology, 1998, 19, 401-405.
Chen P.H., Yang L.X. \& Zhong W.L. Free amino acids components of cystic fluid of Cysticercus cellulosae. Chung Kuo Chi Sheng Chung Hsueh Yu Chi Sheng Chung Ping Tsa Chih, 1990, 8, 181-184.

del Arenal Mena I.P., Bonilla A.C., Moreno-Sanchez R. \& Escamilla J.E. A method for the isolation of tegument syncytium mitochondria from Taenia crassipes cysticerci and partial characterization of their aerobic metabolism. Journal of Parasitology, 1998, 84, 461-468.

Fan P.C., Ma Y.X., KuO C.H. \& Chung W.C. Survival of Taenia solium cysticerci in carcasses of pigs kept at $4^{\circ} \mathrm{C}$. Journal of Parasitology, 1998, 84, 175-177.

Fusser A., Gonzalez D., Plancarte A., Ostrosky P., Montero R., Stephano A. \& Correa D. Praziquantel treatment of brain and muscle porcine Taenia solium cysticercosis. 2. Immunological and cytogenetic studies. Parasitology Research, 1990, 76, 640-642.

Garg M., Gupta R.K., Prasad K.N., Sikora S.S., Pal L., Chawla S., Kumar R., Husain M., Saxena S., Husain N. \& Roy R. Fertility assessment of hydatid cyst by ${ }^{1} \mathrm{H}$ MR spectroscopy. Journal of Surgical Research, 2002a, 106, 196-201.

Garg M., Chawla S., Prasad K.N., Roy R., Sikora S.S., Kumar R., Husain M., Khetrapal C.L. \& Gupta R.K. Differentiation of hydatid cyst from cysticercus cyst by ${ }^{1} \mathrm{H}$ MR spectroscopy. NMR in Biomedicin, 2002b, 15, 320-326.

Glonek T., Kopp S.J., Kot E., Pettegrew J.W., Harrison W.H. \& Cohen M.M. P-31 nuclear magnetic analysis of brain, the perchloric acid extract spectrum. Journal of Neurochemistry, 1982, 39, 1210-1219.

Govindaraju V., Young K. \& Maudsley A.A. ${ }^{1} \mathrm{H}$ NMR chemical shifts and coupling constants for brain metabolites. NMR in Biomedicine, 2000,13, 129-153.

Grewal J.S., Kaur S., Bhatti G., Ganguly N.K., Mahajan R.C. \& MaLla N. Kinetics of humoral and cellular immune responses in experimental cysticercosis in pigs infected with Taenia solium. Indian Journal of Medicine Research, 2000, 111, 43-49.

Gupta R.K., Roy R., Dev R., Husain M., Poptani H., Pandey R., Kishore J. \& BHADURI A.P. Finger printing of Mycobacterium tuberculosis in patients with intracranial tuberculomas by using in vivo, ex vivo, and in vitro magnetic resonance spectroscopy. Magnetic Resonance in Medicine, 1996, 36, 829-833.

Gupta R.K., Vatsal D.K., Husain N., Chawla S., Prasad K.N., Roy R, Kumar R., JHa D. \& Husain M. Differentiation of primary tuberculous from pyogenic brain abscesses with in vivo ${ }^{1} \mathrm{H}$ MR spectroscopy and magnetization transfer MR imaging. American Journal of Neuroradiology, 2001, 22, 1503-1509.

GuTIERREZ Y. Cysticercosis, coenuruses, sparganosis, and proliferating cestode larvae, in: Diagnostic pathology of parasitic infections with clinical correlations. Gutierrez Y. (ed.), Oxford university press, New York, 2000, 635-674.

Hausen S.H. \& McCormack W.E. Application of 13C-filtered ${ }^{1} \mathrm{H}$ NMR to evaluate drug action on glucogenesis and glycogenolysis simultaneously in isolated rat hepatocytes. NMR in Biomedicine, 2002, 15, 313-319.

HuRD H. Echinococcus granulosus: a comparison of free amino acid concentration in hydatid fluid from primary 
and secondary cysts and host plasma. Parasitology, 1989, 98,135

Kirchberger M.A. \& Schwartz I.L. Excitation and contraction of skeletal muscle, in: Physiological basis of medical practice. West J.B. (ed), Williams and Wilkins, BaltimoreLondon, 1984, 58-106.

Kniju A., Casieri C., Carpinelli G., Testa l., Podo F. \& De luca F. Double-resonance J-edited ${ }^{1} \mathrm{H}-\mathrm{NMR}$ detection of [6-13C]D-2-deoxyglucose uptake in glioma cells. NMR in Biomedicine, 2000, 13, 124-128.

KOHLER P. The strategies of energy conservations in helminths. Molecular Biochemistry Parasitology, 1985, 17, 1-18.

Kohli A., Gupta R.K., Poptani H. \& Roy R. In vivo proton magnetic resonance spectroscopy in a case of intracranial hydatid cyst. Neurology, 1995, 45, 562-564.

Kuesel A.C., Sutherland G.R., Halliday W. \& Smith I.C.P. ${ }^{1} \mathrm{H}$ MRS of high-grade astrocytomas: mobile lipid accumulation in necrotic tissue. NMR in Biomedicine, 1994, 7, 149155 .

McManus D.P. \& BRYANT C. Biochemistry, physiology and molecular biology of Echinococcus, in: Echinococcus and hydatid disease. Thompson R.C.A. \& Lymbery A.J. (eds), CAB International, UK, 1995, 135-56.

Nash T.E. \& Neva F.A. Recent advances in the diagnosis and treatment of cerebral cysticercosis. New England Journal of Medicine, 1984, 311, 1492-1496.

Pandit S., Lin A., Gahbauer H., Libertin C.R. \& Erdogan B. MR spectroscopy in neurocysticercosis. Journal of Computer Assisted Tomography, 2001, 25, 950-952.

Pathak K.M., Gaur S.N. \& Kumar D. Epidemiology of strobillar and cystic phase of Taenia solium in certain parts of Uttar Pradesh (India). Indian Journal of Veterinary Medicine, 1983, 4, 17-18.

PATHAK K.M. \& GaUR S.N. Economic implication of porcine cysticercosis. Indian Journal of Veterinary Medicine, 1988, $8,151-153$.

PathaK K.M. \& Gaur S.N. Prevalence and economic implications of Taenia solium taeniasis and cysticercosis in Uttar Pradesh state of India. Acta Leiden, 1989, 57, 197-200.

Poptani H., Gupta R.K., Jain V.K., Roy R. \& Pandey R. Cystic intracranial mass lesions: possible role of in vivo MR spectroscopy in its differential diagnosis. Magnetic Resonance Imaging, 1995, 13, 1019-1029.

Rodriguez-Carbajal J., Boleaga-Duran B. \& Dorfsman J. The role of computed tomography (CT) in the diagnosis of neurocysticercosis. Child's Nervous System, 1987, 3, 199202.

Shukla-Dave A., Gupta R.K., Roy R., Husain N., Paul L., Venkatesh S.K., Rashid M.R., Chabra D.K. \& Husain M. Prospective evaluation of in vivo proton MR spectroscopy in differentiation of similar appearing intracranial cystic lesions. Magnetic Resonance Imaging, 2001, 19, 103-110.

Sweatman B.C., Farrant R.D., Holmes E., Ghauri F.Y., NicholSON J.K. \& LiNDON J.C. $600 \mathrm{MHz}{ }^{1} \mathrm{H}-\mathrm{NMR}$ spectroscpoy of human cerebrospinal fluid: effects of sample manipulation and assignment of resonances. Journal of Pharmacy in Biomedical Analysis, 1993, 11, 651-664.
Venkatesh S.K., Gupta R.K., Paul L., Husain M. \& Husain N. Spectroscopic increase in choline signal is nonspecific marker for differentiation of infective-inflammatory from neoplastic lesions of the brain. Journal of Magnetic Resonance Imaging, 2001, 14, 8-15.

Reçu le 20 juin 2003 Accepté le $1^{\text {er }}$ décembre 2003 